\title{
Determination of Effective Speech Skills of Pediatric Nurses and Affecting Factors
}

\author{
(D) Sibel Küçükoğlu1, (1) Semra Köse1, (1) Aynur Aytekin Özdemir3, (1) Neşe Taşkıran² \\ ${ }^{1}$ Atatürk University Faculty of Nursing, Department of Child Health and Disease Nursing, Erzurum, Turkey \\ 225. End Brigade Command, Primary Care Examination Center, Balıkesir, Turkey \\ 3istanbul Medeniyet University Faculty of Health Sciences, Department of Nursing, İstanbul, Turkey
}

\begin{abstract}
Aim: This descriptive and cross-sectional research aims to determine effective speech skills of pediatric nurses and their affecting factors.

Materials and Methods: The study population consisted of 124 nurses working in pediatric clinics of one university hospital, two state hospitals and two private hospitals located in the Province of Erzurum, Turkey. The research data were obtained using a "Demographic Information Form" and an "Effective Speech scale (ESS)". In the analysis of the data, percentile distributions, averages, t-test, One-Way variance analysis, Kruskal-Wallis variance analysis and Cronbach's alpha coefficient were used. Ethical principles were adhered to when conducting the study.

Results: In the study, it was found that the vast majority of nurses did not receive training to improve effective speaking skills (76.6\%). It was determined that the mean ESS score was $98.40 \pm 11.08$, and that the average score of the nurses who received training on effective speech skills was higher $(p<0.05)$.

Conclusion: In the study, it was determined that the nurses had moderately effective speech skills, and the average ESS score of the nurses who received training on effective speech skills was found to be higher. According to the results of the study, nurses should be supported both in their formal education and working life with activities such as domestic or foreign courses, symposiums, seminars, congresses, etc. in order to improve their effective speech skills professionally.

Keywords: Child, effective speech, nurse
\end{abstract}

\section{Introduction}

Communicating with the other people is an important need for humans who are a social being. Communication, which has many definitions, may be defined as the conveyance of a message by the sender to the receiver through a specific channel (1). People may firstly enjoy their lives, solve their problems, understand their environment better, have the opportunity to make themselves and the others happy and contribute to their control and development by sharing their feelings, thoughts, knowledge and problems through communication involving all moments and fields of life (2). Also, communication is the way to maintain interpersonal relations. A person's ability of self-expression that he/ she uses in relationships can affect the person's feelings, thoughts, behavior and actions toward whomever he/she establishes a dialogue (3). The shortest and most effective way of communication is speaking (1). The speaking skill has the characteristics of both being the starting point of literacy skills and being the most effective way in our social life and communication. According to Özbay (4), speaking is a skill that affects and directs the success, education, work life and private life of a person and allows him/her to become social and not be isolated from society. Effective speech occurs with a harmony of the mental and physical aspects of speaking. Therefore, the prerequisites of effective 
speech involve components such as the coexistence of the grammar rules, the social structure of language and speech competence (5). According to Temizyürek et al. (6); the fact that the conveyance of any kind of message, coded by the speaker, is that having a maximum effect on the listener shows the effectiveness of the speech. The success of occupational groups that are based on human beings, service to the humans and help depends on their communication skills. It is required that people or occupational groups who are continuously in communication with other people know communication techniques very well and use them effectively. Therefore, communication is a tool that one should know technically and have good skills with. Nursing, like all healthcare professionals, is also a profession that serves directly to people and leads to intense communication with people (3). A nurse communicates with people of all ages, races, religions and socio-economic levels. The aim of the nurses in this communication level is to meet the basic needs of the individuals in their daily life activities and help them to cope with their health problems. Therefore, it is important for nurses to have high communication skills in order to evaluate reactions and understand feedback (7). In the communication the nurses establish with both patients and society, they have key roles in many areas ranging from reflecting properly the care he/she provides to professional conveyance of the education he/she has received and the helping principle that he/she aims to achieve. Allocating time for communicating with patients by speaking with them and listening to them enhances the quality of the care, decreases costs and leads to patients being discharged in a shorter time and returning to their work sooner if they work, by helping patients to resume their daily activities. Additionally, it allows hospitals to provide service for more patients in a shorter period (8). A study by Tutuk et al. (9) has demonstrated that effective interpersonal relations and advanced communication skills of nurses created positive effects (being more satisfied with the service, increased motivation to improve, adherence to treatment) on patients. Also, the care-focused effective communication has positive effects on patient care (10). In order to enhance the quality of patient care and patient satisfaction, firstly the communication skills between the nurse and the personnel need to be improved $(11,12)$. When the related literature was examined, it was observed that nurses had problems both with patients and physicians from time to time due to insufficient communication (13-15). It is stated that patients and their relatives feel emotionally better with the effectively established communication; on the other hand, when insufficient communication is established, those receiving care experience uncertainty and dissatisfaction and they feel anxious (16). The pediatric nurse has roles such as prime caregiver, advocate, educator, researcher, manager, coordinator-collaborator and also consulting. With these roles, the nurse helps children and their families to cope with the fears, discomfort and stress associated with diseases and develops his/her skills related to protecting and improving child and family health. In such situations, he/she deals with the feelings of patients closely, understands his/her emotions and thoughts, accepts the situation unconditionally, shows empathy and helps them to solve their problems by using effective communication skills $(17,18)$. Communication is an art and if a child is in question, this art should be better learned and executed. The healthier a child is communicated with, the better his/her mental health is. In the light of this information, this study was conducted in order to determine the effective speech skills of nurses working in children's services and the effective factors.

\section{Materials and Methods}

\section{The Population and Sample of the Study}

This descriptive study was conducted in the pediatric clinics of one university hospital, two state hospitals and two private hospitals in Erzurum between August 2013 and November 2013. In the study, a sampling method was not used and the study was conducted on the whole population. The study was completed for 124 nurses who were working actively in the related clinics and agreed to participate in the study. As 19 nurses did not agree to participate in the study, they were not included in the sample and so $86.7 \%$ of the population were reached in this study. The data were obtained using the "Personal Information Form" prepared by the researchers as a result of a literature review $(9,19,20)$ in order to determine the effective speech skills of the nurses who were working in the pediatric clinics as well as their "Effective Speech scale (ESS)".

\section{Personal Information Form}

This form consisted of a total of 10 questions investigating the socio-demographic characteristics and the work life properties of the nurses (age, educational status, marital status, whether or not they have children, the unit he/ she works in, the working duration at their profession, the working duration at their clinic, the way of work, whether or not they had received training on effective speech etc.).

\section{The Effective Speech Scale}

The scale was developed by Yıldız and Yavuz (19) in 2012 to improve the effective speech characteristics of individuals. The scale consists of 5 subscales: presentation, sound, style and statement, focusing on speaking and paying attention to listeners. The "presentation" subscale consists of 7 items (items 1-7), the "style and statement" subscale consists of 5 items (items 12-16), the "sound" subscale consists of 4 items (items 8-11), the "focusing on speaking" subscale consists of 4 items (items 17-20), and the "paying attention to listeners" subscale consists of 4 items (items 21-24). The items of this 
Likert Type scale are rated as "strongly agree", "agree", "partly agree", "disagree", and "strongly disagree". Minimum 1 point to maximum 5 points can be obtained from each item of the scale. Twenty items on the scale have positive judgment and 4 items have negative judgment out of the total of 24 items. Minimum 24 points and maximum 120 points are obtained from the scale. High scores signifie high effective speech skills of individuals. Yıldız and Yavuz (19) calculated the Cronbach $\alpha$ value of the scale as 0.92. In this study, the Cronbach's $\alpha$ value of the scale was found as 0.90 .

\section{The Data Collection}

The data collection stage had two stages. In the first stage, the information form was filled out by the researchers via a face-to-face interview technique with the nurses who were working in the specified clinics, at their available times, outside of treatment and care hours in a suitable room in the clinic. It took on average 10-15 minutes to fill out this form. In the second stage of the data collection, the researchers observed the nurses between 08:00 and 12:00 in which care and treatment are performed by them most commonly. Although it is a Likert Type Self-report scale, the observation method was preferred in this study as the concept it measures is an abstract one. The nurses were not informed that they would be observed about effective speech with the intention of minimizing being affected. As a result of this observation, both researchers scored the ESS were recorded separately. Then, the concordance between the independent observers

Table I. Distribution of the descriptive characteristics of the nurses

\begin{tabular}{|l|l|l|}
\hline Descriptive characteristic & Number & $\%$ \\
\hline Age (year) & & \\
$18-28$ & 78 & 62.9 \\
$29-39$ & 43 & 34.7 \\
$40-50$ & 3 & 2.4 \\
\hline Marital status & & \\
Married & 63 & 50.8 \\
Single & 61 & 49.2 \\
\hline Child & & \\
Yes & 44 & 35.5 \\
No & 80 & 64.5 \\
\hline Level of education & & \\
Health vocational high school & 21 & 16.9 \\
Associate degree & 11 & 8.9 \\
Undergraduate & 79 & 63.7 \\
Graduate & 13 & 10.5 \\
\hline Year of working & & \\
1-5 year & 72 & 58.1 \\
6-10 year & 35 & 28.2 \\
11 and over & 17 & 13.7 \\
\hline Style of working & & \\
Daytime & 34 & 27.4 \\
Shift & 90 & 72.6 \\
\hline
\end{tabular}

was examined and accordingly, the concordance between the observers was determined as almost perfect.

\section{Ethical Consideration of the Study}

Before starting the study, the ethics committee decision from the Ethics Committee of the Faculty of Health Sciences of Atatürk University (approval number: 05.08.2013/01) and the official permissions from the provincial directorate of health and the specified hospitals were obtained. The participants were informed about the purpose of the study, duration of the study and processes to be performed during the study and their consent was obtained.

\section{Statistical Analysis}

In the assessment of the data; the percentage distribution and mean, independent Samples t-test, One-Way analysis of variance, Kruskal-Wallis and the Cronbach alpha coefficient calculation were applied by using the SPSS 18 software package.

\section{Results}

According to the obtained data, it was determined that $62.9 \%$ of the nurses were in the age group of $18-28$ years, $50.8 \%$ were married, $64.5 \%$ had no child, $63.7 \%$ had a bachelor's degree, $58.1 \%$ had working experience of $1-5$ years and $72.6 \%$ worked in shifts (Table I). When the trainings received by the nurses to develop their effective

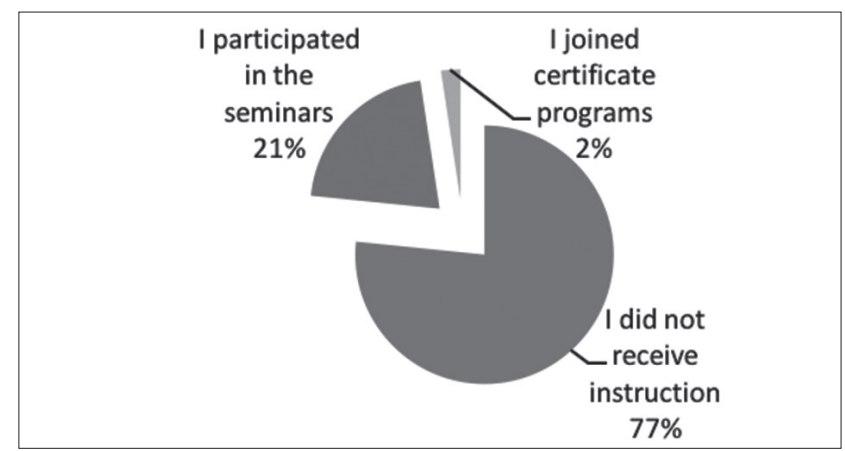

Figure 1. The state of the nurses on receiving training on effective speech skills

Table II. The Effective Speech scale mean scores of the nurses

\begin{tabular}{|c|c|c|c|}
\hline & ESS & $\begin{array}{l}\text { Min and max } \\
\text { values of scale }\end{array}$ & $X \pm S D$ \\
\hline & ESS Total score & $73-120$ & $98.40 \pm 11.08$ \\
\hline 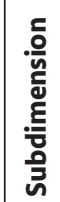 & $\begin{array}{l}\text { Presentation } \\
\text { Sound } \\
\text { Style and statement } \\
\text { Focusing on speaking } \\
\text { Paying attention to } \\
\text { listeners }\end{array}$ & $\begin{array}{l}23-35 \\
11-20 \\
10-25 \\
6-20 \\
10-20\end{array}$ & $\begin{array}{l}30.22 \pm 3.48 \\
16.66 \pm 2.49 \\
20.56 \pm 3.01 \\
15.01 \pm 3.15 \\
15.96 \pm 2.35\end{array}$ \\
\hline
\end{tabular}

SD: Standard deviation, min: Minimum, max: Maximum, X: Mean, ESS: Effective Speech scale 
speech skills were examined in the study, it was determined that $76.6 \%$ of the nurses did not receive training on this subject, $21 \%$ participated in seminars on effective speech and $2.4 \%$ participated in certification programs on this subject (Figure 1). Table II shows the mean scores on the nurses for effective speech skills. When the mean scores obtained by the nurses from the subscales of the scale were examined, the presentation mean score was determined as $30.22 \pm 3.48$, sound mean score as $16.66 \pm 2.49$, style and statement mean score as 20.56 \pm 3.01 , focusing on speaking mean score as $15.01 \pm 3.15$, paying attention to listeners mean score as $15.96 \pm 2.35$ and the ESS total mean score as $98.40 \pm 11.08$. When the distributions of ESS mean scores according to descriptive characteristics of the nurses were examined, it was determined that the nurses who were aged 40 years and over, married and had bachelor's degree had higher

\begin{tabular}{|c|c|c|c|c|c|c|}
\hline Descriptive characteristic & $\begin{array}{l}\text { Presentation } \\
X \pm S D\end{array}$ & $\begin{array}{l}\text { Sound } \\
X \pm S D\end{array}$ & $\begin{array}{l}\text { Style and } \\
\text { statement } \\
X \pm S D\end{array}$ & $\begin{array}{l}\text { Focusing on } \\
\text { speaking } \\
X \pm S D\end{array}$ & $\begin{array}{l}\text { Paying attention } \\
\text { to listeners } \\
X \pm \text { SD }\end{array}$ & $\begin{array}{l}\text { Total } \\
X \pm S D\end{array}$ \\
\hline $\begin{array}{l}\text { Year } \\
18-29 \\
30-39 \\
40 \text { and over }\end{array}$ & $\begin{array}{l}29.81 \pm 3.74 \\
30.79 \pm 2.96 \\
32.67 \pm 1.54\end{array}$ & $\begin{array}{l}16.44 \pm 2.60 \\
17.02 \pm 2.35 \\
17.33 \pm 0.58\end{array}$ & $\begin{array}{l}20.50 \pm 3.12 \\
20.67 \pm 2.87 \\
20.33 \pm 3.21\end{array}$ & $\begin{array}{l}14.73 \pm 3.34 \\
15.51 \pm 2.86 \\
15.00 \pm 1.00\end{array}$ & $\begin{array}{l}15.91 \pm 2.35 \\
16.04 \pm 2.45 \\
16.00 \pm 1.00\end{array}$ & $\begin{array}{l}97.38 \pm 11.34 \\
100.09 \pm 10.84 \\
101.33 \pm 5.13\end{array}$ \\
\hline Test and $p$ value & $\begin{array}{l}K W=3.237 \\
p=0.198\end{array}$ & $\begin{array}{l}K W=1.360 \\
p=0.507\end{array}$ & $\begin{array}{l}K W=0.077 \\
p=0.962\end{array}$ & $\begin{array}{l}\mathrm{KW}=1.319 \\
p=0.517\end{array}$ & $\begin{array}{l}K W=0.040 \\
p=0.980\end{array}$ & $\begin{array}{l}K W=1.526 \\
p=0.466\end{array}$ \\
\hline $\begin{array}{l}\text { Marital status } \\
\text { Married } \\
\text { Single }\end{array}$ & $\begin{array}{l}30.68 \pm 2.89 \\
29.74 \pm 3.97\end{array}$ & $\begin{array}{l}16.65 \pm 2.56 \\
16.67 \pm 2.43\end{array}$ & $\begin{array}{l}20.52 \pm 2.83 \\
20.59 \pm 3.21\end{array}$ & $\begin{array}{l}15.27 \pm 2.77 \\
14.74 \pm 3.51\end{array}$ & $\begin{array}{l}15.89 \pm 2.20 \\
16.03 \pm 2.52\end{array}$ & $\begin{array}{l}99.02 \pm 10.45 \\
97.77 \pm 11.77\end{array}$ \\
\hline Test and $p$ value & $t=1.519 p=0.131$ & $\begin{array}{l}t=0.048 \\
p=0.962\end{array}$ & $\begin{array}{l}t=0.122 \\
p=0.903\end{array}$ & $\begin{array}{l}t=0.940 \\
p=0.349\end{array}$ & $\begin{array}{l}t=0.339 \\
p=735\end{array}$ & $\begin{array}{l}t=0.624 \\
p=0.534\end{array}$ \\
\hline $\begin{array}{l}\text { Have children } \\
\text { Yes } \\
\text { No }\end{array}$ & $\begin{array}{l}30.73 \pm 2.82 \\
29.94 \pm 3.78\end{array}$ & $\begin{array}{l}16.89 \pm 2.44 \\
16.54 \pm 2.52\end{array}$ & $\begin{array}{l}20.39 \pm 2.83 \\
20.65 \pm 3.12\end{array}$ & $\begin{array}{l}15.36 \pm 2.71 \\
14.81 \pm 3.37\end{array}$ & $\begin{array}{l}15.91 \pm 2.27 \\
15.99 \pm 2.41\end{array}$ & $\begin{array}{l}99.27 \pm 10.22 \\
97.93 \pm 11.57\end{array}$ \\
\hline Test and $p$ value & $\begin{array}{l}t=1.211 \\
p=0.228\end{array}$ & $\begin{array}{l}t=0.746 \\
p=0.457\end{array}$ & $\begin{array}{l}t=0.465 \\
p=0.643\end{array}$ & $\begin{array}{l}t=0.931 \\
p=0.353\end{array}$ & $\begin{array}{l}t=0.177 \\
p=0.860\end{array}$ & $\begin{array}{l}t=0.646 \\
p=0.519\end{array}$ \\
\hline $\begin{array}{l}\text { Level of education } \\
\text { Health vocational high school } \\
\text { Associate degree } \\
\text { Undergraduate } \\
\text { Graduate }\end{array}$ & $\begin{array}{l}29.86 \pm 3.71 \\
29.55 \pm 3.27 \\
30.32 \pm 3.43 \\
30.77 \pm 3.90\end{array}$ & $\begin{array}{l}17.00 \pm 2.49 \\
16.18 \pm 2.64 \\
16.58 \pm 2.45 \\
17.00 \pm 2.80\end{array}$ & $\begin{array}{l}20.63 \pm 2.87 \\
18.91 \pm 3.48 \\
20.76 \pm 2.80 \\
20.62 \pm 3.93\end{array}$ & $\begin{array}{l}14.90 \pm 3.25 \\
12.91 \pm 2.63 \\
15.11 \pm 2.96 \\
16.31 \pm 3.90\end{array}$ & $\begin{array}{l}16.81 \pm 2.54 \\
16.09 \pm 2.02 \\
15.73 \pm 2.33 \\
15.85 \pm 2.38\end{array}$ & $\begin{array}{l}99.19 \pm 11.17 \\
93.64 \pm 8.54 \\
98.51 \pm 10.87 \\
100.54 \pm 13.99\end{array}$ \\
\hline Test and $p$ value & $\begin{array}{l}\mathrm{KW}=0.336 \\
\mathrm{p}=0.779\end{array}$ & $\begin{array}{l}K W=0.367 \\
p=0.777\end{array}$ & $\begin{array}{l}K W=1.229 \\
p=0.302\end{array}$ & $\begin{array}{l}K W=2.489 \\
p=0.640\end{array}$ & $\begin{array}{l}K W=1.182 \\
p=0.320\end{array}$ & $\begin{array}{l}K W=0.873 \\
p=0.457\end{array}$ \\
\hline $\begin{array}{l}\text { Years of work } \\
1-5 \text { years } \\
6-10 \text { years } \\
11 \text { years and over }\end{array}$ & $\begin{array}{l}29.72 \pm 3.65 \\
30.97 \pm 3.43 \\
30.76 \pm 2.54\end{array}$ & $\begin{array}{l}16.56 \pm 2.42 \\
16.80 \pm 2.88 \\
16.66 \pm 2.48\end{array}$ & $\begin{array}{l}20.46 \pm 2.97 \\
20.74 \pm 30.02 \\
20.59 \pm 3.32\end{array}$ & $\begin{array}{l}14.43 \pm 3.27 \\
16.09 \pm 3.13 \\
15.24 \pm 2.02\end{array}$ & $\begin{array}{l}15.75 \pm 2.38 \\
16.40 \pm 2.55 \\
15.94 \pm 1.75\end{array}$ & $\begin{array}{l}96.92 \pm 10.67 \\
101.00 \pm 12.54 \\
99.35 \pm 8.96\end{array}$ \\
\hline Test and $p$ value & $\begin{array}{l}\mathrm{KW}=3.820 \\
\mathrm{p}=0.148\end{array}$ & $\begin{array}{l}K W=0.452 \\
p=0.798\end{array}$ & $\begin{array}{l}K W=0.255 \\
p=0.880\end{array}$ & $\begin{array}{l}K W=5.938 \\
p=0.051\end{array}$ & $\begin{array}{l}K W=1.480 \\
p=0.477\end{array}$ & $\begin{array}{l}K W=3.304 \\
p=0.192\end{array}$ \\
\hline $\begin{array}{l}\text { Style of working } \\
\text { Daytime } \\
\text { shift }\end{array}$ & $\begin{array}{l}30.06 \pm 3.17 \\
30.28 \pm 3.61\end{array}$ & $\begin{array}{l}17.03 \pm 2.33 \\
16.52 \pm 2.55\end{array}$ & $\begin{array}{l}19.94 \pm 2.75 \\
20.79 \pm 3.08\end{array}$ & $\begin{array}{l}14.47 \pm 2.42 \\
15.21 \pm 3.38\end{array}$ & $\begin{array}{l}15.71 \pm 2.18 \\
16.06 \pm 2.42\end{array}$ & $\begin{array}{l}97.21 \pm 9.73 \\
98.86 \pm 11.58\end{array}$ \\
\hline Test and $p$ value & $\begin{array}{l}t=0.311 \\
p=0.756\end{array}$ & $\begin{array}{l}t=1.013 \\
p=0.313\end{array}$ & $\begin{array}{l}t=1.404 \\
p=0.163\end{array}$ & $\begin{array}{l}t=1.169 \\
p=0.245\end{array}$ & $\begin{array}{l}t=0.737 \\
p=0.463\end{array}$ & $\begin{array}{l}t=0.738 \\
p=0.462\end{array}$ \\
\hline $\begin{array}{l}\text { Training in effective speaking } \\
\text { Yes } \\
\text { No }\end{array}$ & $\begin{array}{l}32.14 \pm 3.48 \\
29.63 \pm 3.28\end{array}$ & $\begin{array}{l}17.31 \pm 2.42 \\
16.46 \pm 2.49\end{array}$ & $\begin{array}{l}22.00 \pm 2.72 \\
20.12 \pm 2.97\end{array}$ & $\begin{array}{l}17.00 \pm 3.33 \\
14.40 \pm 2.84\end{array}$ & $\begin{array}{l}16.97 \pm 2.47 \\
15.65 \pm 2.24\end{array}$ & $\begin{array}{l}105.41 \pm 10.76 \\
96.26 \pm 10.33\end{array}$ \\
\hline Test and $p$ value & $\begin{array}{l}t=3.549 \\
p=0.001\end{array}$ & $\begin{array}{l}t=1.615 \\
p=0.109\end{array}$ & $\begin{array}{l}t=3.048 \\
p=0.003\end{array}$ & $\begin{array}{l}t=4.137 \\
p=0.000\end{array}$ & $\begin{array}{l}t=2.697 \\
p=0.008\end{array}$ & $\begin{array}{l}t=4.137 \\
p=0.000\end{array}$ \\
\hline
\end{tabular}

SD: Standard deviation, KW: Kruskal-Wallis, X: Mean 
ESS mean scores but the difference between groups was statistical insignificant ( $p>0.05)$. In terms of the state of the nurses who had or had not received training on effective speech, it was determined that the nurses who had received training obtained higher scores from the overall scale and its subscales compared to those nurses who had not and the difference between ESS total and subscales was significant except for the subscale of sound (Table III, p<0.05).

\section{Discussion}

Communication contains elements like volume, tone and stress of voice, speaking speed, type of breathing, pausing, facial expression, eye movements, bearing, the distance between people, gestures, dressing style as well as the words spoken (21). In the study, it was determined that the nurses had moderate effective speech skills (Table II) and it was thought that this situation should be enhanced. In the literature, it is stated that medical errors are observed more when healthcare professionals do not establish professional, effective communication $(22,23)$. Voice is required to be used appropriately for effective speech during communication (19). In the study by Akkaya (24), it was stated that individuals experienced problems about failing to focus on speaking during communication. The individuals also stated that they had problems in establishing communication due to voice, tone, stress along with the above-mentioned problem (24). The tone, volume, and variability of voice, hearing of voice by everyone in an environment, a clear, comprehensible speaking speed and inflection when required allow communication to be more effective (19). The education process is important in developing communication skills in nursing. Some of the goals are increasing self-confidence and respect levels of students during both formal courses and clinical/field practices within this process as well as their personal and professional development (25). It is possible to say that the results of effective speech skills of nurses with higher educational levels and experience are higher. Speech skill develops through training like all other skills. What is intended with speech training is that a person becomes able to tell about his/her feelings, thoughts and desires (26). Although speech skill is innate, correct and effective speech is a skill gained through training. The speech skill is innate but correct and appropriate speaking of a person is shaped through education received during the school life (27). An individual who speaks well can express himself/herself exactly and correctly. Especially, the quality of life of individuals is affected by the success obtained owing to speech and the impressive power of speech and the importance of training should be understood (21). When the training received by the nurses to develop their effective speech skills was examined in this study, it was determined that a great majority of them did not receive training on this subject, only $21 \%$ of them participated in seminars on effective speech skills and $2.4 \%$ participated in certification programs on this subject (Figure 1). In the study by Kurudayıoğlu (21), activities to be performed to improve speech skill were drawn attention to and it was stated that one of the leading factors in improving the speech skill was training. Similarly, in his study in which he offered his suggestions on improving the speech skill, Doğan (28) also emphasized that receiving training for effective speech allowed speech to become more effective and planned. In this study, when the scale mean scores obtained from the nurses were examined in terms of the state of receiving training on effective speech, it was found that the nurses who had received training had higher scores on the overall scale and its subscales compared to the nurses who had not (Table III, $\mathrm{p}<0.05$ ). Not receiving training on communication may cause a failure to express feelings and thoughts clearly, comprehensibly and meaningfully and to correctly understand what is intended to be expressed (19). This situation reveals itself for nurses who received training on effective communication with their high scores in the style-statement. In the study by Arifoğlu and Razı (29), the mean score of the Empathic Tendency scale of students who had received training on communication were found to be higher than ones who had not received information. In a study conducted by Thomas and Cohn (30), it was stated that the training of communication skills and the way of communicating with patients left a positive and lasting impression on the trust patients felt in health professionals. The aim of the speech lessons provided in educational institutions is to have students gain the skills to express their feelings and thoughts in a correct, appropriate and effective way according to grammatical rules $(5,25)$. Therefore, starting from formal education courses, courses on bringing effective speech skills to nursing students should be added to the curriculum and subjects and certification programs related to effective speech should be organized within the scope of in-service training in their professional lives.

\section{Study Limitations}

It is a limitation that the research was done with nurses working in the child clinic in the hospitals where the data were collected. Therefore, the results obtained without research can be generalized to nurses in this research group.

\section{Conclusion}

In this study, it was determined that the great majority of the nurses had not received any training to improve the effective speech skills, the total mean score of the effective speech was moderate and the nurses who had received training on effective speech skills obtained higher ESS mean scores. In accordance with these results, it is recommended that institutions should give support to nurses to participate in national and international activities 
like courses, symposiums, congresses etc., in order to help them improve their effective speech skills in professional standards, nurses should have a more comprehensive education on improving their effective speech skills during their undergraduate education, the education should not be limited to undergraduate education and should be continued with in-service training. Effective speech skills should be the primary responsibility of all members of the health team as they improve patient safety, quality and satisfaction. Institutions and units should determine policies in this field and aim to have their personnel improve in this subject. Studies with larger groups should be conducted with nurses working in hospitals with different structures.

\section{Ethics}

Ethics Committee Approval: The study was approved by the Atatürk University Faculty of Health Sciences Ethics Committee (approval number: 05.08.2013/01).

Informed Consent: Consent form was filled out by all participants.

Peer-review: External and internal peer-reviewed.

\section{Authorship Contributions}

Surgical and Medical Practices: S.K., A.A.Ö., S.K., N.T., Concept: S.K., A.A.Ö., Design: S.K., A.A.Ö., Data Collection and Processing: S.K., N.T., Analysis and Interpretation: S.K., A.A.Ö., S.K., Literature Search: S.K., A.A.Ö., S.K., Writing: S.K., S.K.

Conflict of Interest: No conflict of interest was declared by the authors.

Financial Disclosure: The authors declared that this study received no financial support.

\section{References}

1. Orhan S, Kırbaş A, Topal Y. International periodical for the languages. Literature and History of Turkish or Turkic Volume 2012;7:1097-115.

2. Uyer G. Management in Nursing Services. 2nd ed. İstanbul, Union Press, 1996;58.

3. Bingöl G, Demir A. Communication skills of students of Amasya medical vocational school. GoztepeTrh 2011;26:152-9.

4. Özbay M. Speech concepts and speech. National Education 2005;168:116-25.

5. Suikkala A, Leino-Kilpi $\mathrm{H}$. Nursing student-patient relationship: a review of the literature from 1984 to 1998. I Adv Nurs 2001;33:42-50

6. Temizyürek F, Erdem I, Temizkan M. Speech Education (Oral Expression). 4th ed, Ankara, Pegem Publications; 2011.

7. Kumcağız H, Yılmaz M, Balcı Çelik S, Aydın Avcı I. Communication skills of nurses: Samsun sample. Dicle Med I 2011;38:49-56.

8. Heath HBM. Foundation in Nursing: Theory And Practice. Philadelphia, Mosby Com, NY, 1995:275-6.
9. Tutuk A, Al D, Doğan S. Determining communication skills and emphatic levels of nursing students. Cumhuriyet University Nursing Journal 2002;6:36-41.

10. Boscart MV. A communication intervention for nursing staff in chronic care. I Adv Nurs 2009;65:1823-32.

11. Quisling KE. Resident orientation: nurses create a program to improve care coordination. Am / Nurs 2009;109(11 Suppl):26-8.

12. Parlayan MA, Dökme S. Evaluation of Nurse and Patients' Communication Levels in Private Hospitals: An Example of Hospital. KSÜ Journal of Social Sciences 2016;13:265-84.

13. Tjia I, Mazor KM, Field T, Meterko V, Spenard A, Gurwitz JH. Nurse-physician communication in the long-term care setting: Perceived barriers and impact on patient safety. I Patient Saf 2009;5:145-52.

14. Cantwell BM, Ramirez AJ. Doctor-patient communication: a study of junior house officers. Med Educ 1997;31:17-21.

15. Markova T, Broome B. Effective communication and delivery of culturally competent health care. Urol Nurs 2007;27:239-42.

16. Wilkinson S, Linsell L, Perry R, Blanchard K. Communication skills training for nurses working with patients with heart disease. British Journal of Cardiac Nursing 2008;3:475-81.

17. Kılıçarslan Törüner E, Büyükgönenç L. Child Health Basic Nursing Approaches. Ankara, Göktuğ Publishing, 2012.

18. Whaley LF, Wong DL. Essentials of Pediatric Nursing. 5th ed. The CV, Mosby Co. St Lovis; 1995;1102-16.

19. Yıldız DÇ, Yavuz M. Study of developıng effective speech scale. Turkish studies-international periodical for the languages. Literature and history of turkish or Turkic 2012;7:319-34.

20. Karadağ $M$, Işık $O$, Cankul $i \mathrm{H}$, Abuhanoğlu H. Evaluatıon of communıcation skılls of physicians and nurses. Journal of Gazi University Faculty of Economics and Administrative Sciences 2015;17:160-79.

21. Kurudayıoğlu M. Activities for developing speech training and speaking skills. TÜBAR-XIII 2003:287-309.

22. Thomas CM, Bertram E, Johnson D. The SBAR communication technique: teaching nursing students professional communication skills. Nurse Educ 2009;34:176-80.

23. de Almeida Araujo IM, Da Silva RM, Bonfim IM, Fernandes AF. Nursing communication in nursing care to mastectomized women: a grounded theory study. Rev Lat Am Enfermagem 2010;18:54-60.

24. Akkaya A. The opinions of teacher candidates about speech problems. Mustafa Kemal University Journal of Social Sciences Institute 2012;20:405-20.

25. Aktaş Ş, Gündüz O. Written and Oral Expression. Ankara, Akçağ Publications, 2001.

26. Sever S. Turkish Teaching and Full Learning. Ankara, Anı Publications; 1997.

27. Uçgun $D$. The factors affecting the speaking education. Journal of Social Sciences Institute 2007;22:59-67.

28. Doğan Y. Recommendation for the development of speech skills. Turkish Journal of Educational Sciences 2009;7:185-204.

29. Arifoğlu B, Razı CS. Management Course Academic Achievement Averages of First Class Nursing Students. Deuhyo Ed 2011;4:7-11.

30. Thomas V), Cohn T. Communication skills and cultural awareness courses for healthcare professionals who care for patients with sickle cell disease. J Adv Nurs 2006;53:480-8. 